\title{
A Study on the Performance of Hedge Fund and Market -Timing -Ability
}

\author{
Jian-Fa Li ${ }^{1}$ Kuang-Hua Hsu ${ }^{2}$ Po-Ru Yeh ${ }^{3}$ \\ ${ }^{1}$ Department of Finance, Chaoyang University of Technology, Taichung County, Taiwan, R. O. C., \\ E-mail: jfli@cyut.edu.tw \\ ${ }^{2}$ Department of Finance, Chaoyang University of Technology, E-mail: khhsu@mail.cyut.edu.tw \\ ${ }^{3}$ Department of Finance, Chaoyang University of Technology, E-mail: gare1230675@yahoo.com.tw
}

\begin{abstract}
The fund manager always pronounces "the high returns from hedge fund are along with low risk. Is the performance of hedge fund manager really good? In this study, the market-timing ability and performance consistency on hedge fund manager are tested. The Sharpe ratio was employed to implement the consistency of performance for mutual fund in the previous literature. Due to the non-normally distributed of returns of financial assets, the adjusted Sharpe ratio is employed in this study. As Dowd (1999) suggested, the adjusted Sharpe ratio in which the true risk is evaluated by value at risk (VaR). In the period of Asian flu and (Long Term Capital, LTCM) event, we found the hedge fund returns shocked badly, but it is not significant. Although the hedge funds performance is positive correlation during pre and post-term, but it is not significant. The change in structure of the hedge fund returns is hardly found. It also shows that hedge fund manager could rapidly react. Moreover, we found performance consistency for the hedge fund, despite that the manager does not have market-timing ability. The result was contradictory. The reason could be attributed to "bonus" system, the hedge fund manager could get "incentive fee", and it is run up to $20 \%$. Perhaps, the hedge fund manager will seek achievement to lead to market-timing ability not well. According to the adjusted Sharpe ratio, we found the Event-driven risk arbitrage median hedge fund could provide better performance to investors, no matter when the investors invest, they will get higher profit.
\end{abstract}

Keywords: hedge fund, adjusted Sharpe ratio, performance consistence, market-timing ability, VaR.

\section{Introduction}

The hedge fund manager always pronounces "the high return from hedge fund is along with the low risk. Is the performance of hedge fund really good? In this study, the market-timing ability and performance consistency on hedge fund performance are tested. Ackermann, McEnally and Ravenscraft(1999) showed the performance of hedge fund outperforms that of the mutual fund significantly. In the previous literature, however, the hedge fund performance is seldom consistency in average or medium-size hedge fund.(Brown,Goetzman and Ibbotson(1999); Agarwal and Naik(2000); Brown,Goetzmann and Park(2001), Fung,Xu,Yau(2002)).

As to the market-timing ability of the fund manager, it has been measured broadly (Treynor and Mazuy (1965), Fabozzi and Francis (1979) Henriksson and Merton (1981), and Chang and Lewellen (1984)). Fung, Xu, Yau (2002) pointed out the fund manager hedges the risk in the bear market through the mechanism similar to that in the option to protect the hedge fund value. Accordingly, the market-timing ability is an important subject. Fung, $\mathrm{Xu}, \mathrm{Yau}$ (2002) analyzed global hedge fund performance; they confirmed the global hedge fund has the excellent ability of selecting stocks. However, the negative market-timing ability is more notable than positive market-timing ability. It shows the managers are short of market-timing ability. The portfolio of hedge fund could be composed from different target markets. The further research indicate that $\beta$ (market risk) in the downturn market is higher than that in up market. The hedge fund would not protect the assets value. That contradicts with pronounce of the hedge fund manager. Ennis and Sebastian (2003) intended to add the hedge fund into the portfolio to raise the portfolio return. They found out that it could not increase the return of the portfolio. It shows hedge fund not to make profit in downturn market. During, the bubble economy in United Stated of America, researcher found out that hedge fund manager has good market-timing ability. 
Based on normal distribution, the Sharpe ratio was created. The returns of financial data are seldom normally distributed. Furthermore, Schwager (1985) pointed out the default of standard deviation, which just shows volatility not true risk. Investors do not care about volatility, and mind loss or profit. Dowd (1999) employed VaR for standard deviation in Sharpe ratio, called as "adjusted Sharpe ratio". If the portfolio return is normally distributed, then Sharpe ratio is equal to adjusted Sharpe ratio and the performance the rank the performance among portfolio is consistency. On the other hand, the value of Sharpe ratio would be biased. Instead of standard deviation, the VaR would overcome the bias.

We employ the adjusted Sharpe ratio to measure hedge fund return. Moreover, we implement to test the hedge fund manager market-timing ability and performance consistency. We test whether the change in structure exists in the return of the hedge fund during serious financial event.

The organization of this paper is as follows: In section 2, we introduce the methodology consisting of Sharpe ratio with value at risk, Spearman rank test and market-timing ability model. Section 3 presents conclusions

\section{Methodology}

As to the performance of hedge fund, we employ the Spearman Rank Correlation Test. If it is not significant positive correlation between earlier stage and later stage, the result shows that hedge fund last performance could not predict future trend. The Spearman Rank statistic is formulated as

$$
\gamma_{s}=1-\frac{6 \sum \mathrm{d}^{2}}{\mathrm{n}\left(\mathrm{n}^{2}-1\right)}
$$

where $r_{s}$ denotes the coefficient of Spearman Rank Correlation; $d$ is the rank difference in ex-period and back and $\mathrm{n}$ is number of hedge fund

In this study, the market-timing ability model is introduced (to confirm that whether the fund manager holds the market-timing ability or not. The model could be referred as (Henriksson and Merton(1981))

$$
\left.R_{j, t}-R_{f, t}=\alpha_{2}+\beta_{1 j}\left(R_{m, t}-R_{f, t}\right)+\beta_{2 j}\left[\left(R_{m, t}-R_{f, t}\right) D_{t}\right)\right]+\varepsilon_{j, t}
$$

where $R_{f}$ represents riskless interest and $R_{j, t}$ is the return of hedge fund in $\mathrm{j}$ period at $\mathrm{t}$ time. ; $\mathrm{R}_{\mathrm{m}}$ is the remarkable index return (hedge fund goal market) $; \mathrm{D}$ is equal to 0 as $R_{m}-R_{f}<0$; otherwise, $D$ is equal to 1 .

Dowd (1999) introduced the value-at-risk (VaR) to Sharpe ratio. The VaR represents true risk level. If the return series is normally distributed, the Sharpe ratio is equal to the Sharpe ratio with VaR (so called adjusted Sharpe ratio). The performance rank is the same. If the returns is normal distributed, the Sharpe ratio will have bias. Therefore, the researchers substitute standard deviation with VaR.

The Sharpe ratio, $\mathrm{S}_{1}$, with $\mathrm{VaR}$ is formulated as follows

$$
S_{1}=\frac{E\left(R_{p}\right)-R_{f}}{\operatorname{VaR}}
$$

Where $R_{p}$ is the rate of return in portfolio and $\mathrm{R}_{\mathrm{f}}$ is denotes riskless interest

\section{Conclusions}

In this study, there are four portfolios: Event-Driven Hedge Fund, Fund of Fund Hedge Fund, Global Hedge Fund and Market-Neutral Hedge Fund. We test the performance consistency of hedge fund and market-timing ability of fund manager.

In the period of Asian flu and Long Term Capital, LTCM) event, we found the hedge fund return is shocked badly, but it is not significant. Although the hedge funds performance is positive correlation during pre and post-term, but it is not significant. When financial shocks were happened, hedge fund managers cannot keep hedge fund performance to be excellent as pre-term. The investors should notice it to prevent suffering great loss. The hedge fund return does not have structure changes. It shows that hedge fund manager could rapidly react. As to timing-ability, Fung, Xu and Yau (2002) found that global hedge fund managers do not have timing-ability. This study found not only global hedge fund managers not to hold timing-ability but also fund of fund, market-neutral, event-driven hedge fund managers. The results confirm us that the hedge fund managers could master the trend in the bull market and get profit but they cannot avoid the downside risk. Therefore, we found out that the hedge fund performance consistency, but we fail to confirm that the fund manager holds the market-timing ability. The result was contradictory. The potential is attributed to "bonus" system, the hedge fund manager could obtain "incentive fee", and it is run up to $20 \%$. The hedge fund manager could seek achievement to lead to market-timing ability not well.

We attempt to calculate the Sharpe ratio with value at risk (VaR) to rank the performance of the hedge fund in the rest of the study. According to the adjusted Sharpe ratio, we found the Event-driven risk arbitrage median hedge fund could provide better performance to investors, no matter when the investors invest, they will get higher profit.

\section{References}

[1] C. Ackermann, R. McEnally, and D. Ravenscraft, "The Performance of Hedge Funds: Risk, Return, and Incentives," Journal of Finance, Vol.54 (3), pp, 833-874, 1999. 
[2] V. Agarwal, and N.Y. Naik, "Multi-Period Performance Persistence Analysis of Hedge Funds," Journal of Financial and Quantitative Analysis, Vol.35 (3), pp.327-342, 2000.

[3] S. Brown, W.N. Goetzmann, and R.G. Ibbotson, "Offshore Hedge Fund: Survival and Performance, 1989-95," Journal of Business, Vol.72 (1), pp.91-117, 1999.

[4] S. Brown, W.N. Goetzmann, and J. Park, "Careers and Survival: Competition and Risk in the Hedge Fund and CTA Industry," Journal of Finance, Vol.56(5), pp.1869-1886, 2001.

[5] K. Dowd, "A Value at Risk Approach to Risk-Return Analysis," Journal of Portfolio Management, Vol.25 (4), pp. 60-67, 1999.

[6] R. M. Ennis, and M. D. Sebastian, "A Critical Look at the Case for Hedge Funds: Lessons from the Bubble," Journal of Portfolio
Management, Vol.29 (4), pp.103-12, 2003

[7] H. G. Fung, X. E. Xu, and J. Yau, "Global hedge funds: Risk, return, and market timing," Financial Analysts Journal, Vol.58(6), pp.19-31,2002.

[8] R. D. Henriksson, and R.C. Merton, “On Market Timing and Investment Performance: Statistical Procedures for Evaluating Forecasting Skills," Journal of Business, Vol.54 (4), pp.513-34, 1981.

[9] T. Schneeweis, and G. Martin, "The Benefits of Hedge Funds: Asset Allocation for the Institutional Investor," Journal of Alternative Investments, Vol. 4, pp. 7-26, 2001.

[10] W. F. Sharpe, "Capital asset prices: A theory of market equilibrium under conditions of risk," Journal of Finance, Vol.19, (3), pp.425-42, 2003. 